\title{
ELEMENTARY PROOF OF THE LEFT MULTIDIMENSIONAL HERMITE-HADAMARD INEQUALITY ON CERTAIN CONVEX SETS
}

\author{
LADISLAV MATEJÍČKA
}

Abstract. The left Hermite-Hadamard inequality of several variables for convex functions on certain convex compact sets is proved via elementary approach, independently of Choquet theory.

Mathematics subject classification (2010): Primary 26A51; Secondary 26A46, 26 A48.

Keywords and phrases: Convex, concave function, Hermite-Hadamard inequality, mean value.

\section{REFERENCES}

[1] M. BessenyeI, The Hermite-Hadamard inequality on Simplices, American Math. Monthly, 115, 4 (2008), 339-346.

[2] S. S. Dragomir, On Hadamard's inequality for the convex mappings defined on a ball in the space and applications, Math. Inequal. Appl., 3 (2000), 177-187.

[3] S. S. Dragomir, On Hadamard's inequality on a disk, J. Inequal. Pure Appl. Math., 1 Article 2 (2000), available at http://jipam.vu.edu.au/volumes.php.

[4] S. S. DRAGOMIR, On the Hadamard's inequality for convex functions on the co-ordinates in a rectangle from the plane, Taiwanese J. Math., 5 (2001), 775-788.

[5] S. S. DragomiR And C. E. M. PeARCE, Selected Topics on Hermite-Hadamard Inequalities, RGMIAMonographs, Victoria University, 2000.

[6] B.GAVReA, On Hadamard's inequality for the convex mappings defined on a convex domain in the space, J. Inequal. Pure Appl. Math., 1 Article 9 (2000), available at http://jipam.vu.edu.au/ volumes.php.

[7] J. HADAMARD, Étude sur les propriétés des fonctions entières et en particulier d'une fonction considérée par Riemann, J. Math. Pures Appl., 58 (1893), 171-215.

[8] G. Choquet, Les cônes convexes faiblement complets dans l'Analyse, Proc. Intern. Congr. Mathematicians, Stockholm (1962), 317-330.

[9] D. S. MitrinoviĆ AND I. B. LACKović, Hermite and convexity, Aequationes Math., 28 (1985), 229232.

[10] C.P. Niculescu And L.-E. Persson, Convex Functions and Their Applications. A Contemporary Approach, CMS Books in Mathematics, vol. 23, Springer-Verlag, New York, 2006.

[11] C. P. Niculescu And L.-E. Persson, Old and new on the Hermite-Hadamard inequality, Real Anal. Exchange, 29 (2003/2004), 619-623.

[12] C. P. NiculesCU, The Hermite-Hadamard inequality for convex functions of a vector variable, Math. Inequal. Appl., 5 (2002), 619-623.

[13] R. R. Phelps, Lectures on Choquet's Theorem, 2nd ed., Lecture Notes in Math. no. 1757, SpringerVerlag, Berlin, 2001. 